УДК 37.02

\title{
ВЛИЯНИЕ ТЕМПЕРАМЕНТА УЧАЩИХСЯ ДХШ НА ПРОФЕССИОНАЛЬНЫЙ ВЫБОР
}

\author{
Ермолаева Дарья Юрьевна \\ Салтыкова Галина Михайловна \\ к. п. н., доцент \\ МПГУ
}

Аннотация: в статье будет проанализирована взаимосвязь типов темперамента и личных предпочтений учащихся детской художественной школы по направлениям профессиональной деятельности. Методы исследования -сравнительно-сопоставительный и фактический, на основе собственного опыта преподавания.

Ключевые слова: профориентация, темперамент, художественная деятельность, профессиональное самоопределение, дополнительное образование, свойства нервной системы.

\section{INFLUENCE OF TEMPERAMENT OF STUDENTS FOR A PROFESSIONAL CHOICE}

\section{Ermolaeva Daria Yurievna Saltykova Galina Mikhailovna}

\begin{abstract}
: the article will analyze the relationship between the types of temperament and personal preferences of students of the children's art school in the areas of professional activity. Research methods - comparative-comparative and factual, based on their own teaching experience.

Key words: career guidance, temperament, artistic activity, professional selfdetermination, additional education, properties of the nervous system.

Правильно выбранная профессия - это возможность реализовывать свой интеллектуальный и творческий потенциал, а также условие для дальнейшей успешной жизнедеятельности. Профессиональное самоопределение - ведущая форма проявления активности личности в процессе профессионального становления. Е.А. Климов рассматривает профессиональное самоопределение в




\section{МОЛОДЕЖНАЯ НАУКА КАК ФАКТОР И РЕСУРС ИННОВАЦИОННОГО РАЗВИТИЯ}

качестве одного из важнейших проявлений психического развития человека, как процесс его включения в профессиональное сообщество и более широко - в социальное сообщество [2, с. 19]. С этой проблемой человек сталкивается на стадии получения общего среднего образования. Помимо общей направленности трудовой деятельности, большинство профессий имеют внутренние, более узкие специализации. В творческих визуально-графических видах деятельности существует следующее разделение: изобразительное искусство, дизайн (графический, web-дизайн, дизайн-среды) декоративноприкладное искусство, архитектура и др. Учащиеся (абитуриенты), выбирающие направление будущего обучения и дальнейшую профессию, в связи с недостатком опыта, стоят перед сложной проблемой выбора. Помимо собственных представлений о профессии на подростка влияют внутренние факторы - психофизиологические данные, личностные качества и возможности $[1$, c. 105]. Эти особенности, определяются внутренними установками, психологией, работой нервной системы и, как правило, проявляются в ходе обучения. В художественном образовании самоопределение происходит путем апробирования ребенком различных художественных видов деятельности. Это возможно также в рамках дополнительного образования. Например, при обучении в художественной школе.

Темперамент - это совокупность устойчивых, индивидуальных свойств человека, обусловливающих динамические особенности его психической деятельности. Зная темперамент обучаемого, ему можно помочь облегчить выбор будущей профессии. И. П. Павлов разработал классификацию темперамента на основе свойств нервной системы [3, с. 9]:

- сильный, уравновешенный, подвижный тип («живой», по И.П. Павлову - сангвинический темперамент;

- сильный, уравновешенный, инертный тип («спокойный», по И.П. Павлову - флегматический темперамент;

- сильный, неуравновешенный, с преобладанием возбуждения («безудержный» тип, по И.П. Павлову — холерический темперамент);

- слабый тип («слабый», по И.П. Павлову - меланхолический темперамент).

С целью изучения влияния темперамента на выбор будущей профессиональной художественной деятельности была проведена серия опросов обучающихся 10-17 лет детского-художественного образовательного учреждения Арт-школа «Рыжий кот» в г. Обнинске. Обучающиеся были 207 
разделена на две группы: младшие подростки $(\mathrm{N}=20)$ в возрасте 10-13 лет и старшие подростки $(\mathrm{N}=15)$ в возрасте 14-17 лет. В ходе исследования были подобраны следующие методики - тест на определение темперамента по А.Н. Белову «Формула темперамента», а также разработан опросник, основанный на личных предпочтениях подростков по направлениям художественной деятельности.

Рассмотрим соотношение ведущих типов темперамента личности среди двух возрастных групп младших и старших подростков по результатам диагностик по методике А.Н. Белова [4].

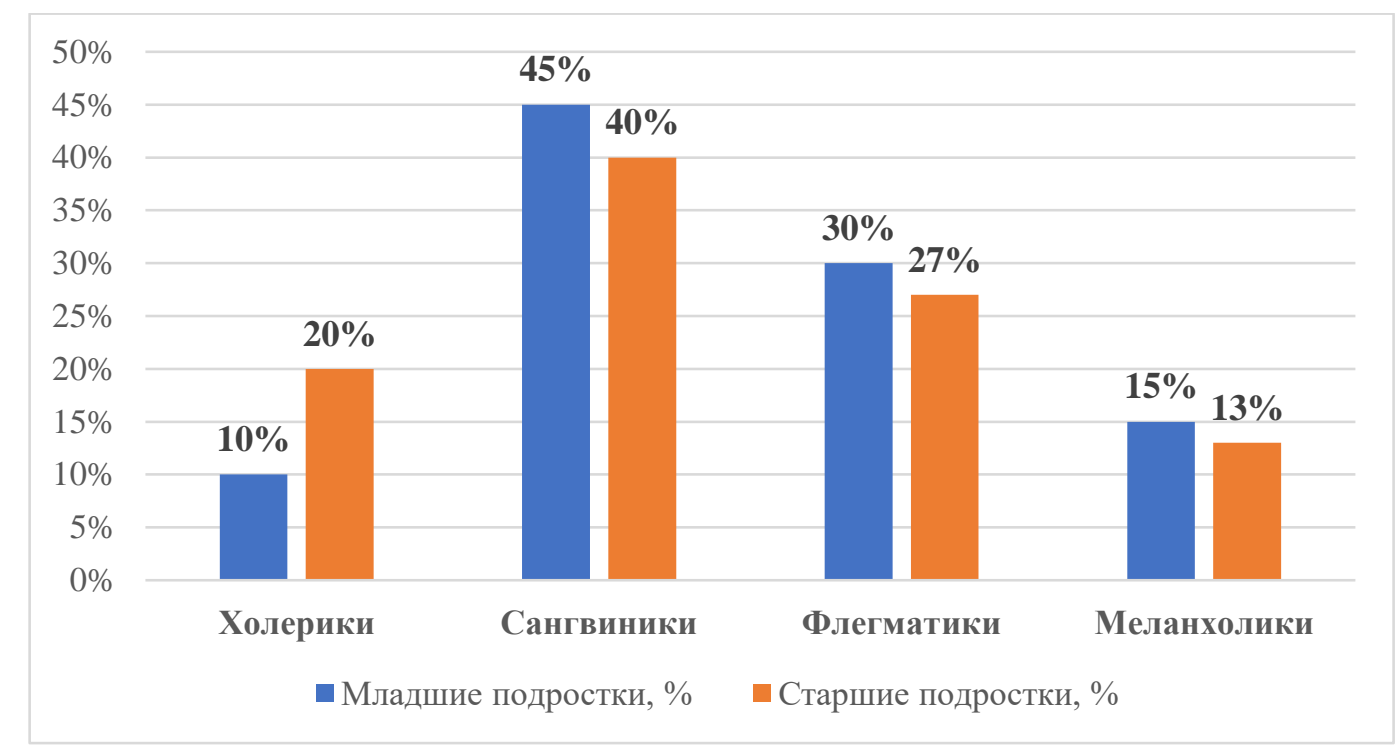

\section{Рис. 1. Соотношение ведущих типов темперамента личности среди возрастных групп младших и старших подростков по результатам} диагностики по методике А.Н. Белова

Как видно по диаграмме (рис. 1) распределение соотношение типов темперамента в обеих возрастных группах приблизительно одинаковое. В ходе опроса «Определение предпочтений будущей профессии в художественной деятельности» учащемуся необходимо было выбрать профессию, в которой он на данный момент себя представляет. За основу были взяты наиболее востребованные профессии в творческих визуально-графических видах деятельности (рис. 2). Профессии были разделены на две условные группы «активные» и «неактивные», в основе деления такие параметры как: работа в коллективе, быстрота реакции, работа с информацией, социальная активность и др. 


\section{МОЛОДЕЖНАЯ НАУКА КАК ФАКТОР И РЕСУРС ИННОВАЦИОННОГО РАЗВИТИЯ}

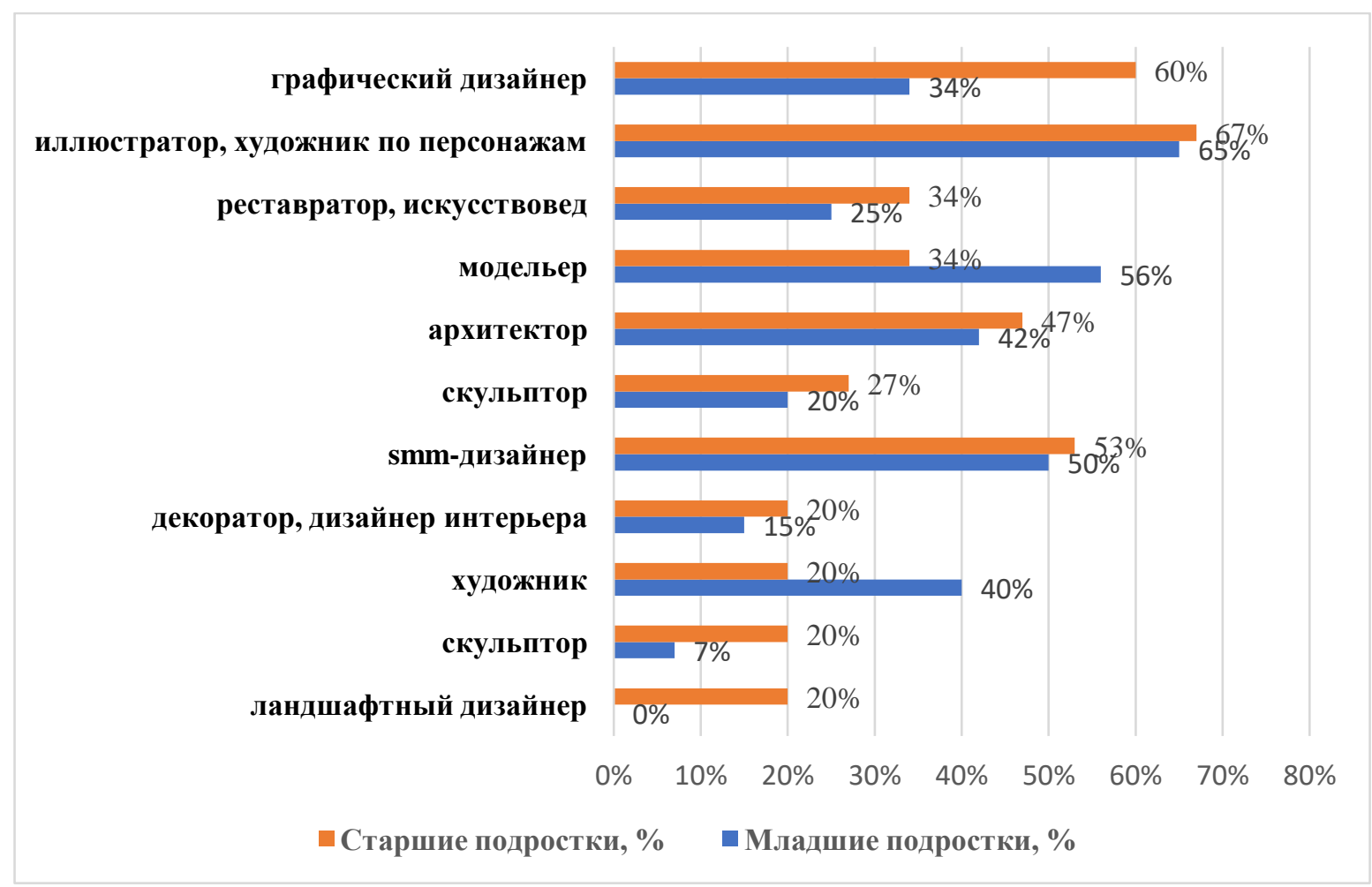

\section{Рис. 2. Определение предпочтений будущей профессии}

Впоследствии были сопоставлены результаты двух опросов, на основе которых выявлена следующая корреляция. Сангвиники выбирают условно «активные» направления деятельности, связанные с работой в команде, проектной деятельностью, такие как smm-дизайнер, дизайнер интерьера. Холерики также выбирают «активные» профессии, но связанные с частой сменной деятельности, например, графический дизайнер, иллюстратор. Флегматики и меланхолики, наоборот, предпочитают условно «неактивные» профессии, связанные с анализом информации, работой с мелкими деталями. Например, меланхолики видели себя в роли искусствоведа, реставратора и свободного художника, а флегматики отдавали преимущество таким профессиям как web-дизайнер и архитектор. Однако, необходимо помнить, что «чистым» темперамент практически не встречается. Как правило один из типов темперамента в характере человека преобладает, а другой выражен менее ярко (например, сангвиник-флегматик или холерик-меланхолик в соотношении $80 \times 20)$.

Исходя из вышесказанного, можно предположить, что в выборе будущей профессии немаловажную роль играет взаимосвязь темперамента и личных 
предпочтений подростка. Знание способностей, индивидуальных особенностей, предпочтений, темперамента учащегося даст преподавателю возможность облегчить выбор учащегося в профессиональном самоопределении учащегося.

\section{Список литературы}

1. Белоусова В.В Профессиональное самоопределение школьников и студентов в сфере информационных технологий / Информатика и образование, №3, 2007, - 104-106

2. Климов Е.А. Психология профессионального самоопределения: учеб. пособие для студ. высш. учеб. заведений / - М.: Издательский центр «Академия» 2010. - $304 \mathrm{c.}$

3. Симонов П. В., Ершов П.М. Темперамент. Характер. Личность. М.: Наука, 1984. - 163 с.

4. Тест на темперамент A.Н. Белова [Электронный ресурс]. - URL: https://aqm.by/upload/iblock/aa6/96.pdf

(С) Д.Ю. Ермолаева, Г.М. Салтыкова, 2020 